\section{The Potential Use of Metamitron as a Chemical Fruit-thinning Agent in Mandarin}

\author{
Ockert P.J. Stander ${ }^{1,3}$, Johané Botes ${ }^{2}$, and \\ Cornelius Krogscheepers ${ }^{2}$
}

AdDitional INDEX wORDs. Citrus reticulata, flowering, fruit quality, leaf carbohydrates, plant growth regulator

\begin{abstract}
Summary. Under conditions of profuse flowering and excessive fruit set, citrus (Citrus sp.) fruit need to be thinned to increase the size of remaining fruit, reduce the intensity of alternate bearing, or both. Metamitron was recently developed as a chemical fruit-thinning agent for apple (Malus $\times$ domestica) and pear (Pyrus communis), and it inhibits photosynthesis and is thought to transiently reduce the carbohydrate pool in fruit trees. Citrus trees are sensitive to carbohydrate stress during and immediately after flowering, but the response of citrus to foliar treatment with a photosynthesis inhibitor, such as metamitron, is unknown. The purpose of this study was to evaluate metamitron for its effects on leaf carbohydrates and its ability to chemically thin citrus fruitlets. Significant fruit-thinning effects were found in all the experiments conducted over two seasons. A $300 \mathrm{mg} \cdot \mathrm{L}^{-1}$ metamitron treatment reduced leaf sugars and leaf total carbohydrates, and consistently reduced the total number of fruit per tree in both seasons in 'Nadorcott' mandarin (Citrus reticulata), irrespective of the timing of application. In the second season, a reduction in fruit yield was reported with an increase in metamitron concentration, both in mass and number of fruit per tree. A

$150 \mathrm{mg} \cdot \mathrm{L}^{-1}$ metamitron treatment in November had no fruit-thinning effects, and fruit yield was not different from the control. The application of metamitron did not increase the fruit size of 'Nadorcott' mandarin and had no direct effect on other fruit quality attributes in either season. Metamitron can be used as a chemical fruitthinning agent to reduce fruit numbers in 'Nadorcott' mandarin, but an increase in fruit size or quality should not be expected.
\end{abstract}

I $n$ South Africa and elsewhere in the world, the use of synthetic plant growth regulators (PGRs) as chemical fruit-thinning agents is a common cultural practice of citrus fruit production to increase fruit size and other important quality attributes (Koch, 1995; Rabe et al., 1995; Stander and Cronjé, 2016). Successful fruit thinning increases individual fruit size by altering the leaf-to-fruit ratio, which results in more carbohydrates, mineral elements, and water available to remaining fruit (Guardiola and García-Luís, 1997; Mesejo et al., 2003). Fruit thinning can also be used to overcome alternate bearing

\footnotetext{
We thank Wiehan Pietersen and Piet Carinus for allowing access to their orchards in Stellenbosch, and Citrus Research International (Pty) Ltd for financial support. We also express our appreciation to Schalk Van der Merwe from Adama South Africa (Pty) Ltd for providing metamitron.

${ }^{1}$ Citrus Research International, Department of Horticultural Science, University of Stellenbosch, Private Bag X01, 7602, Matieland, Stellenbosch, South Africa

${ }^{2}$ Department of Horticultural Science, University of Stellenbosch, Private Bag X01, 7602, Matieland, Stellenbosch, South Africa

${ }^{3}$ Corresponding author. E-mail: jakkie@sun.ac.za.
}

https://doi.org/10.21273/HORTTECH03913-17
(Monselise and Goldschmidt, 1982). Because a large fruit load in an "on" year inhibits the induction of flowers and development of fruit in the following season, fruit thinning can reduce the probability of an "off" year and minimize the alternate bearing cycle (Stander and Cronjé, 2016). For these purposes, two formulations of synthetic auxins are available to use as chemical fruit-thinning agents in South Africa; i.e., 2,4-dichlorophenoxy propionic acid and 3,5,6-trichloro2 -pyridil oxyacetic acid (Agustí et al., 1994a, 1994b, 2002; El-Otmani et al., 1996; Guardiola and García-Luís, 2000; Rabe et al., 1995). These PGRs are applied during or directly after phase I of citrus fruit development [from full bloom in October until middle December for the Southern Hemisphere (SH)] (Bain, 1958) and act by inducing ethylene-related abscission of fruitlets and also cause direct stimulation of cell growth and an increase in fruit size (Agustí et al., 1994a, 1994b). The commercial use of some of these PGRs, however, are in danger of being decommissioned because of the reduction in the minimum residue levels permitted by some of the fruit export markets (Cronjé and Stander, 2016). Should this happen, South African citrus growers, who export $\approx 60 \%$ to $65 \%$ of their crop (South African Citrus Growers Association, 2016) would have no chemical fruit-thinning option at their disposal.

Metamitron is a commercial chemical fruit-thinning agent that was recently developed for use in apple and pear (McArtney et al., 2012; Stern, 2014). Metamitron is a photosynthesis-inhibiting active ingredient that disrupts the photosynthetic apparatus by temporarily inhibiting electron transfer between the primary and secondary quinones of photosystem II. Consequently, carbon fixation and the production of adenosine 5 '-triphosphate are inhibited (McArtney et al., 2012). In apple, metamitron is active for 7-10 d after application (Stern, 2014), and thinning of fruitlets is thought to be a result of a temporal limitation in carbohydrate supply to

\begin{tabular}{llll}
\hline $\begin{array}{l}\text { Units } \\
\text { To convert U.S. to SI, } \\
\text { multiply by }\end{array}$ & U.S. unit & SI unit & $\begin{array}{l}\text { To convert SI to U.S., } \\
\text { multiply by }\end{array}$ \\
\hline 29,574 & $\mathrm{fl} \mathrm{oz}$ & $\mu \mathrm{L}$ & $3.3814 \times 10^{-5}$ \\
29.5735 & $\mathrm{fl} \mathrm{oz}$ & $\mathrm{mL}$ & 0.0338 \\
0.3048 & $\mathrm{ft}$ & $\mathrm{m}$ & 3.2808 \\
3.7854 & gal & $\mathrm{L}$ & 0.2642 \\
2.54 & inch(es) & $\mathrm{cm}$ & 0.3937 \\
25.4 & inch $(\mathrm{es})$ & $\mathrm{mm}$ & 0.0394 \\
0.4536 & $\mathrm{lb}$ & $\mathrm{kg}$ & 2.2046 \\
28.3495 & $\mathrm{oz}$ & $\mathrm{g}$ & 0.0353 \\
28,350 & $\mathrm{oz}$ & $\mathrm{mg}$ & $3.5274 \times 10^{-5}$ \\
0.001 & $\mathrm{ppm}$ & $\mathrm{mg} \cdot \mathrm{g}^{-1}$ & 1,000 \\
1 & $\mathrm{ppm}$ & $\mathrm{mg} \cdot \mathrm{L}^{-1}$ & 1 \\
0.001 & $\mathrm{ppm}$ & $\mathrm{mL} \cdot \mathrm{L}^{-1}$ & 1,000 \\
1 & $\mathrm{ppt}$ & $\mathrm{mg} \cdot \mathrm{mL}^{-1}$ & 1 \\
2.2417 & ton $(\mathrm{s}) / \mathrm{acre}$ & $\mathrm{Mg} \cdot \mathrm{ha}^{-1}$ & 0.4461 \\
$\left({ }^{\circ} \mathrm{F}-32\right) \div 1.8$ & ${ }^{\circ} \mathrm{F}$ & ${ }^{\circ} \mathrm{C}$ & $\left({ }^{\circ} \mathrm{C} \times 1.8\right)+32$ \\
& & &
\end{tabular}


developing fruitlets (McArtney and Obermiller, 2012). The short-term disruption of the photosynthetic apparatus results in a lower level of available photosynthates and causes the abscission of the weakest competing fruitlets, which increases assimilate availability to individual fruit when the effect of metamitron wears off(Basak, 2011; Lafer, 2010; McArtney and Obermiller, 2012). In apple and pear, metamitron is usually applied when fruitlets have the highest demand for assimilates, 2 to 3 weeks after full bloom, and at a fruitlet diameter of $10 \mathrm{~mm}$ (Stern, 2014).

In citrus, competition between reproductive organs for energy supply from carbohydrates is one of the most important factors affecting fruit set and eventual fruit size (Iglesias et al., 2003; Mataa et al., 1996; Rivas et al., 2006; Ruiz et al., 2001; Schaffer et al., 1985). Previous studies have shown that a shortage of carbohydrates during November-drop (SH) or Junedrop (Northern Hemisphere), also called physiological fruit drop, can lead to excessive abscission of fruitlets (Goldschmidt, 1999; Guardiola and García-Luís, 2000; Iglesias et al., 2007). Because metamitron reduces the photosynthetic ability and ultimately also the size of the assimilate pool, it can be hypothesized that metamitron foliar spray application to citrus trees during or shortly after the physiological fruit drop period could result in fruit thinning. However, the effects of metamitron on citrus leaves and carbohydrate assimilation are unknown.

The objectives of this study were to determine 1 ) the effects of different concentrations $(75,150$, and 300 $\mathrm{mg} \cdot \mathrm{L}^{-1}$ ) of metamitron foliar spray treatment on the concentrations of different components of leaf carbohydrates in citrus and 2) the potential of different timings of metamitron treatments as a chemical fruit-thinning agent; i.e., $\approx 30$ and $60 \mathrm{~d}$ after full bloom (DAFB).

\section{Materials and methods Plant material and experimental site}

'Miho Wase' satsuma mandarin (Citrus unshiu) trees, 17 years from budding onto 'Troyer' citrange (Citrus sinensis $\times$ Poncirus trifoliata) rootstock were used in a preliminary experiment in an experimental orchard in Stellenbosch, South Africa (lat. $33^{\circ} 94^{\prime} \mathrm{S}$, long. $18^{\circ} 87^{\prime} \mathrm{E}$ ). In the subsequent experiments, a commercial orchard of 6-year-old 'Nadorcott' mandarin trees budded onto 'Carrizo' citrange rootstock was used (lat. $33^{\circ} 93^{\prime} \mathrm{S}$, long. $18^{\circ} 81^{\prime} \mathrm{E}$ ). Both experimental sites are located in the Western Cape province of South Africa, which is one of five climatically diverse citrus growing regions in South Africa and experiences cold, Mediterranean-type climatic conditions. The region receives an annual rainfall of between 400 and $650 \mathrm{~mm}$, with most occurring from May to August (winter).

The orchards were cultivated, pruned, and sprayed according to good agricultural practices. The 'Satsuma' mandarin trees were watered using a microjet-sprinkler irrigation system and the 'Nadorcott' mandarin trees were watered using a drip irrigation system with four emitters per tree. The water supply in each orchard amounted to a total of $\approx 8000 \mathrm{~L} /$ tree per annum. All trees received consistent and grower-standard fertilizer applications, with the rate of application based on annual leaf mineral nutrient analysis and a target fruit yield of $60-70 \mathrm{Mg} \cdot \mathrm{ha}^{-1}$.

\section{Treatments and experimental design}

All the experiments were set up in a randomized complete block design. In the preliminary experiment, the following treatments were replicated six times: an untreated control, and a metamitron [Nevis $(15 \% \mathrm{w} / \mathrm{w}$ metamitron); Adama ${ }^{\circledR}$, Cape Town, South Africa] branch treatment applied at 75,150 , and $300 \mathrm{mg} \cdot \mathrm{L}^{-1}$ a.i. No wetting agent was added to spray mixtures of foliar treatments as per recommendation by the registration holder of Nevis. An individual tree represented a block and a vegetative branch within each tree, a single treatment replication $(n=6)$. Treatments were applied with a hand-sprayer until the point of runoff, on 22 Apr. 2015. Because of a generally strong autonomous phenological growth habit of branches in mandarin trees, branch experiments can be used as an effective model to extrapolate results to wholetree scenarios (Monselise et al., 1983). All branches were located on the outside of the northwestern side of the tree canopy at a height of $\approx 1.5 \mathrm{~m}$ above the orchard floor.
In Expt. 2, $300 \mathrm{mg} \cdot \mathrm{L}^{-1}$ metamitron was applied to eight whole-tree replications $(n=8)$ on 5 Nov. 2015 $(\approx 30 \mathrm{DAFB})$ when the fruitlets had an average transverse diameter of $\approx 8 \mathrm{~mm}$ and on 5 Dec. $2015(\approx 60$ DAFB) when the fruitlets had an average transverse diameter of $\approx 15 \mathrm{~mm}$. Treatments included an untreated control. In Expt. 3, 300 and $150 \mathrm{mg} \cdot \mathrm{L}^{-1}$ metamitron were applied to seven whole-tree replications $(n=7)$ on 7 Nov. $2016(\approx 30$ DAFB) when the fruitlets had an average transverse diameter of $\approx 8 \mathrm{~mm}$ and compared with an untreated control. The foliar spray treatments were applied until the point of runoff at a rate of $\approx 4 \mathrm{~L}$ spray solution per tree using a backpack mist-blow sprayer $\left(\right.$ Stihl $^{\circledR}$ SR430; Andreas Stihl, Pietermaritzburg, South Africa) set at droplet size $2(1=$ fine droplet size, $5=$ coarse droplet size). To avoid drift from different treatment replications onto others, buffer trees were left untreated between treated and control trees in the same row, as well as buffer rows between treated rows. All trees were selected for uniformity in health. The trees were uniform in canopy size, trunk circumference, and had a uniform and evenly distributed fruit load.

\section{Data collection}

LEAF SAMPLING AND PREPARATION. Mature leaves of similar size were sampled from the third to fifth (middle) position on fully hardened off, non-fruiting, and purely vegetative shoots. All shoots had triangular internodes, a length of $\approx 15 \mathrm{~cm}$, and were located on the outside of the tree canopy at a height of $\approx 1.5 \mathrm{~m}$ above the orchard floor. A composite leaf sample consisted of eight leaves that were collected from each of the four shoots from each replication between 8:00 and 10:00 AM on each sampling date. After sampling, the leaves were kept cool and washed with distilled water, before being frozen at $-80{ }^{\circ} \mathrm{C}$, and freeze-dried (Christ Beta 1-8 LD Freeze Dryer; Martin Christ Gefriertrocknungsanlagen, Osterode am Harz, Germany). The leaves were ground to a fine powder with an analytical grinder (Yellow line, Al0; IKA-Werke, Staufen, Germany) and stored at $-80^{\circ} \mathrm{C}$ until analysis. 
Table 1. Fruit quality attributes of control and metamitron fruit-thinning treatments in 'Nadorcott' mandarin at time of maturity in 2016 and 2017.

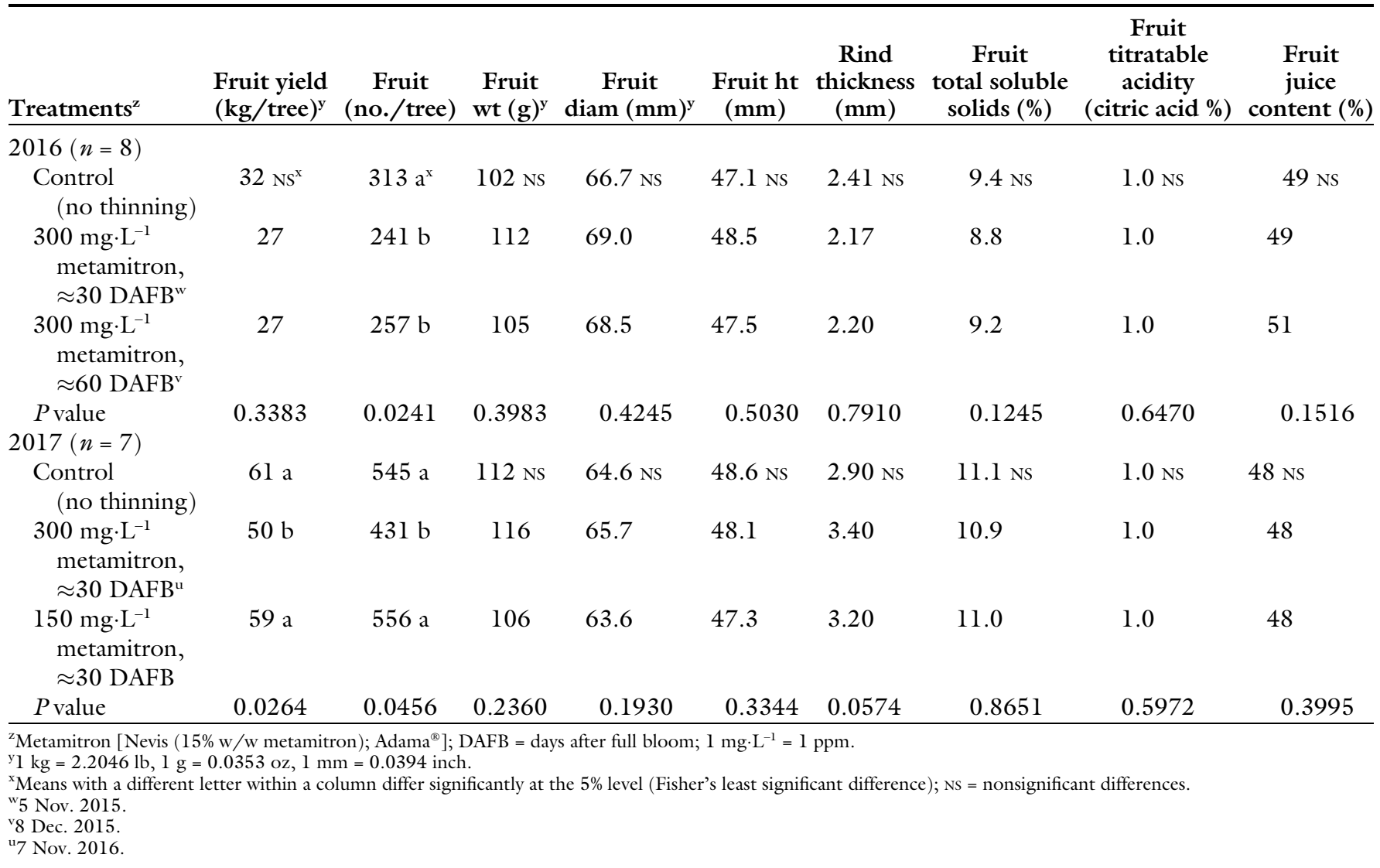

LEAF CARBOHYDRATE ANALYSIS. Total sugars were extracted from $100 \mathrm{mg}$ of dried leaf sample with $5 \mathrm{~mL} 80 \%$ ethanol at $80{ }^{\circ} \mathrm{C}$ for $1 \mathrm{~h}$. The extraction process was repeated twice following the first extraction and the respective supernatants pooled. The pellets were then extracted three times with $5 \mathrm{~mL}$ deionized water at $80{ }^{\circ} \mathrm{C}$ for $24 \mathrm{~h}$ for the determination of total water-soluble polysaccharides. The leaf starch content was determined from the remaining pellet by quantifying the glucose released following an enzymatic digestion of the residue for $17 \mathrm{~h}$ at $60^{\circ} \mathrm{C}$, with the amyloglucosidase enzyme [AMG (Sigma Aldrich, Aston Manor, South Africa)].

The $80 \%$ ethanol, water, and AMG enzyme extracts were analyzed for total soluble sugars using the phenol-sulfuric acid assay (Brummer and Cui, 2005). Briefly, a volume of $20 \mu \mathrm{L}$ of each of the respective extracts was added to $180 \mu \mathrm{L}$ deionized water, $200 \mu \mathrm{L}$ phenol $\left(5 \mathrm{~mL} \cdot \mathrm{L}^{-1}\right)$, and $1000 \mu \mathrm{L}$ concentrated sulfuric acid $\left(\mathrm{H}_{2} \mathrm{SO}_{4}\right)$. Absorbance was determined on a spectrophotometer (Cary
50 Series; Varian, Mulgrave, Australia) at $490 \mathrm{~nm}$, after $30 \mathrm{~min}$, against a blank prepared for the standard. A standard curve for glucose concentrations was prepared, diluting $0,50,100,150$, and $200 \mu \mathrm{L}$ glucose stock solution $\left(0.10 \mathrm{mg} \cdot \mathrm{mL}^{-1}\right)$ with deionized water, to a final volume of $200 \mu \mathrm{L}$. The sugar concentrations were expressed as milligrams per gram leaf dry weight and are referred to as leaf sugar and leaf total starch content. The sum values collectively contribute to the total leaf carbohydrate content.

Fruit Growth. On the day of treatment, five fruit were randomly selected and tagged on each replication at a height of $1.5 \mathrm{~m}$ above the orchard floor. Initial fruit diameter was measured using an electronic caliper (CD-6" C; Mitutoyo Corp, Tokyo, Japan), and thereafter monthly measurements were made using electronic fruit size measure (EFM) and data logger instruments (EFM \& Data Logger; Güss Manufacturing, Strand, South Africa). The measurements were used to calculate the treatment effects on fruit growth rate.
Fruit yield and Quality. Commercial harvest of fruit commenced at the beginning of August, when fruit were fully mature and after fruit quality measurements complied with specifications established by fruit export markets, and was completed by the end of August. One week before the orchard was to be commercially harvested, a sample of 12 randomly selected fruit per data tree was collected to determine the effects of treatments on fruit quality attributes; i.e., fruit size (diameter and weight), rind thickness, total soluble solids (TSS), titratable acidity (TA), and juice percentage. Fruit diameter was measured using an electronic caliper. The fruit were cut longitudinally to evaluate treatment effects on the fruit internal quality and rind thickness. An electronic caliper was used to measure the rind thickness on opposite sides of each fruit, to calculate each fruit's average rind thickness. A citrus fruit juicer $\left(\right.$ Sunkist ${ }^{\circledR}$, Chicago, IL) was used to extract the juice from each fruit, whereupon juice percentage could be calculated by dividing the weight of the juice by the total fruit 
weight. A refractometer (PR-32 Palette; Atago, Tokyo, Japan) was used to measure the TSSs content, and TA (888 Titrando; Metrohm, Herisua, Switzerland) was measured and expressed as the citric acid percent. The sugar to acid ratio was calculated by dividing the TSS by the citric acid (TA) content (TSS:TA). To determine the treatment effects on the total fruit yield, experimental trees were stripped and harvested individually before the start of commercial harvest.

Statistical analysis. STATISTICA data analysis software (version 13; Dell, Round Rock, TX) was used to analyze the data. Analysis of variance (ANOVA) or repeated-measures ANOVA was performed when responses were repeated on the same respondent. Mean separations were carried out using Fisher's least significant difference test, where applicable, at $P \leq 0.05$.

\section{Results and discussion}

Significant fruit-thinning effects were found in the two experiments conducted over two seasons in 'Nadorcott' mandarin. Metamitron treatment at $300 \mathrm{mg} \cdot \mathrm{L}^{-1}$ on 'Nadorcott' mandarin consistently reduced the total number of fruit per tree by $20 \%$ to $25 \%$ in both seasons, irrespective of the timing of application (Table 1). For two metamitron treatments evaluated in the preliminary experiment in 'Satsuma'; i.e., 150 and $300 \mathrm{mg} \cdot \mathrm{L}^{-1}$, leaf sugars and leaf total carbohydrates were lower compared with those of the control leaves, l d after treatment (Fig. 1). The effects of a $300 \mathrm{mg} \cdot \mathrm{L}^{-1}$ metamitron treatment were more persistent, and lower total sugars, starch, and total carbohydrates were measured in leaves up to $7 \mathrm{~d}$ after treatment in the preliminary experiment (Fig. 1) and up to $60 \mathrm{~d}$ after treatment in the whole-tree experiment (Fig. 2). In season 2 , there was a reduction in the fruit yield with an increase in metamitron concentration, both in $\mathrm{kg}$ and in the number of fruit per tree (Table 1). The $300 \mathrm{mg} \cdot \mathrm{L}^{-1}$ November treatment thinned significantly more fruit compared with the untreated control and the $150 \mathrm{mg} \cdot \mathrm{L}^{-1}$ treatment (Table 1). A lower concentration, $150 \mathrm{mg} \cdot \mathrm{L}^{-1}$ metamitron treatment had no effect on fruit thinning and suggests that the treatment

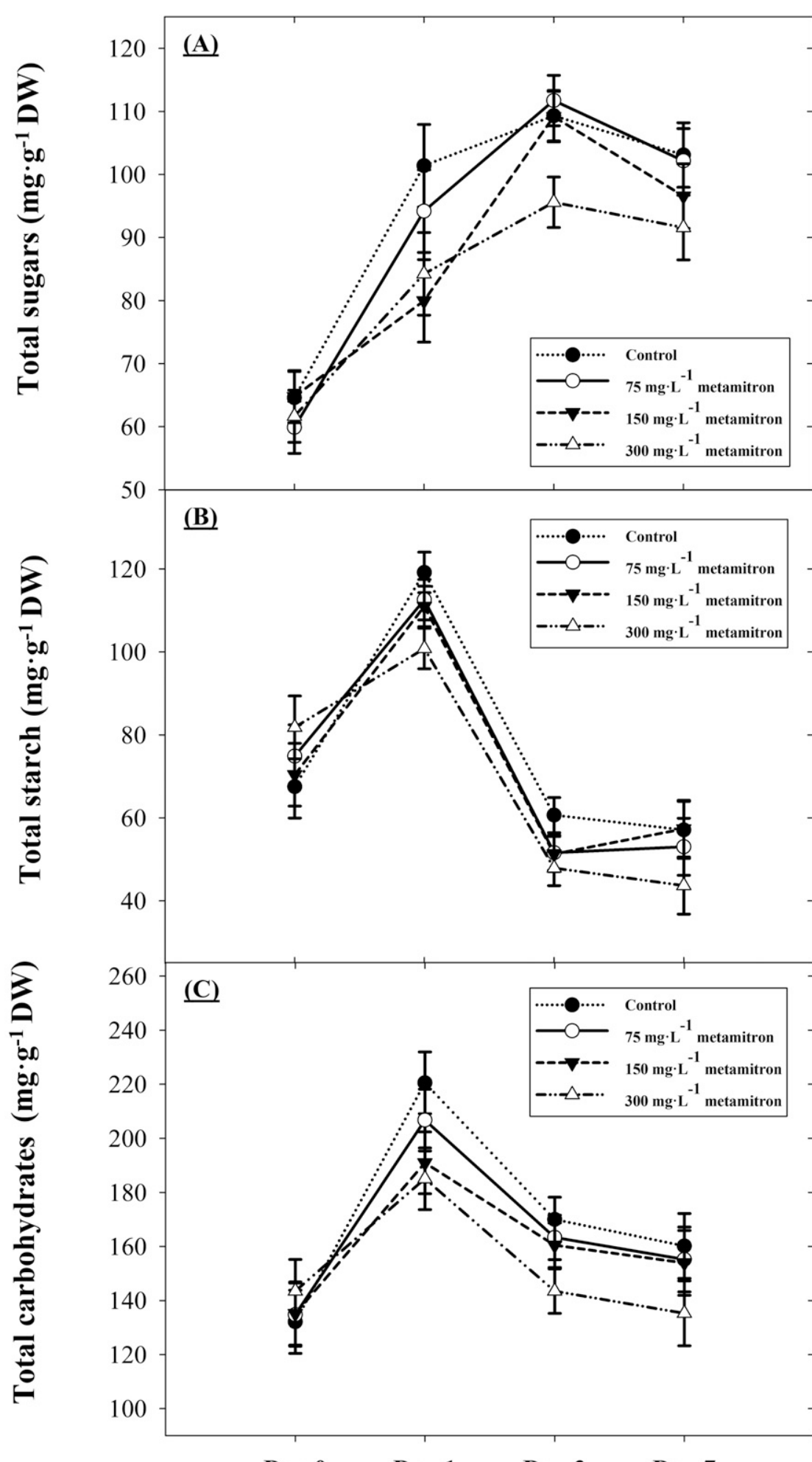

Day $0 \quad$ Day $1 \quad$ Day $3 \quad$ Day 7

Fig. 1. Effects of three different concentrations of metamitron on leaf carbohydrates in 'Miho Wase' satsuma mandarin expressed as total sugars (A), total starch (B), and total carbohydrates (C). Data are expressed as means of six branch replications $(n=6)$. The error bars indicate the $\mathrm{SE} ; 1 \mathrm{mg} \cdot \mathrm{g}^{-1}=1000 \mathrm{ppm}$, $1 \mathrm{mg} \cdot \mathrm{L}^{-1}=1 \mathrm{ppm}$.

did not affect carbon assimilation to the same extent as a $300 \mathrm{mg} \cdot \mathrm{L}^{-1}$ treatment. Metamitron efficacy depends on the length of time the photosynthetic apparatus is inhibited, the extent to which the assimilate level 


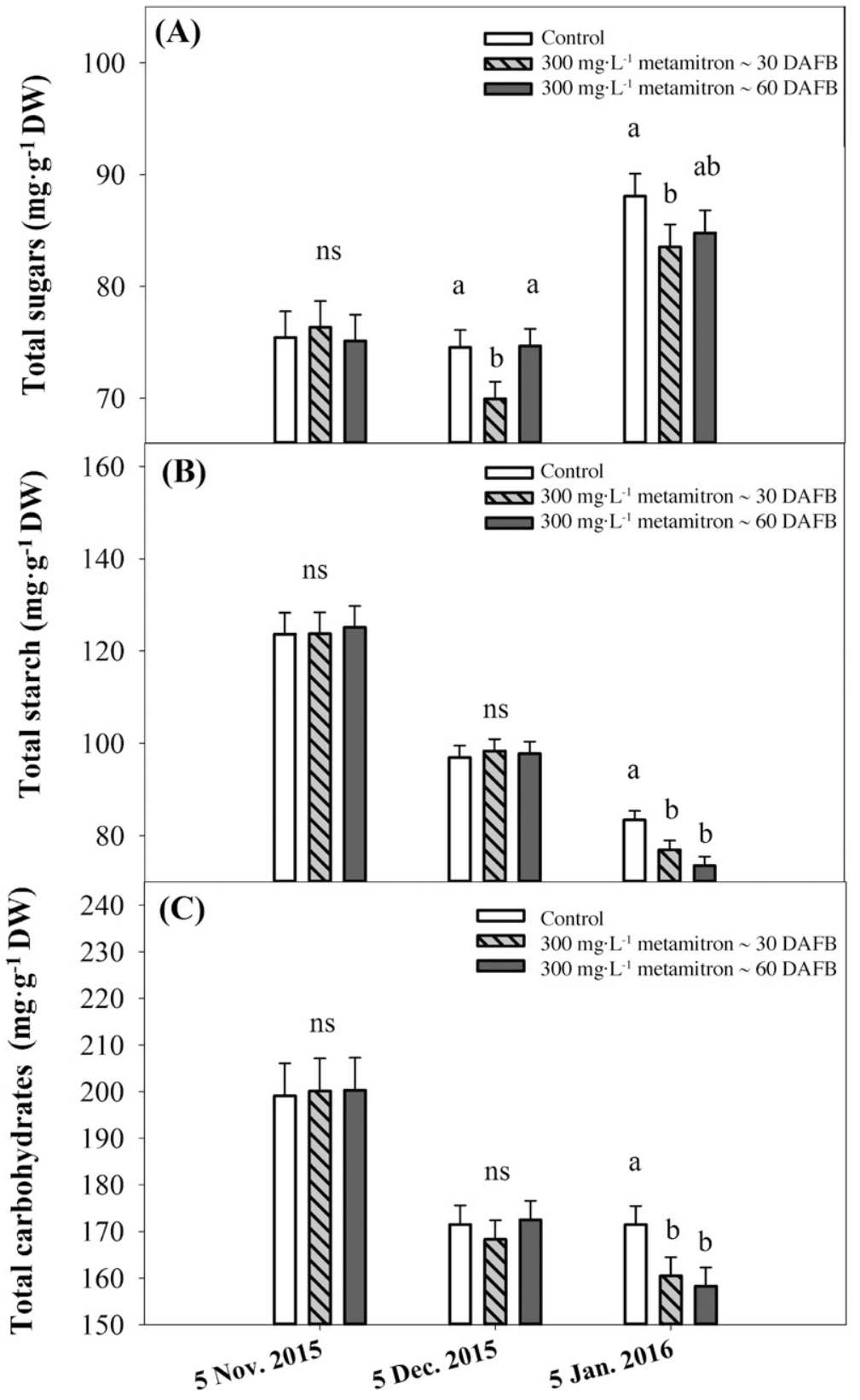

Fig. 2. Effects of two different metamitron treatments; i.e., $300 \mathrm{mg} \cdot \mathrm{L}^{-1}$ metamitron applied in Nov. $2015[\approx 30 \mathrm{~d}$ after full bloom (DAFB)] and $300 \mathrm{mg} \cdot \mathrm{L}^{-1}$ metamitron applied in Dec. $2015(\approx 60 \mathrm{DAFB})$ on leaf carbohydrates expressed as total sugars (A), total starch (B), and total carbohydrates (C) in 'Nadorcott' mandarin. Data are expressed as means of seven whole-tree replications $(n=8)$. Different letters indicate significant differences at the $5 \%$ level (Fisher's least significant difference). Means followed by the same letter indicate no significant difference. $\mathrm{NS}=$ nonsignificant difference. The error bars indicate the $\mathrm{SE} ; 1 \mathrm{mg} \cdot \mathrm{L}^{-1}=1 \mathrm{ppm}, 1 \mathrm{mg} \cdot \mathrm{g}^{-1}=1000 \mathrm{ppm}$.

in the tree is reduced, and the vulnerability of the crop to lower carbohydrate levels in the tree (McArtney et al., 2012). The influence of environmental conditions on the leaf photosynthetic capacity would, therefore, affect the efficacy of a metamitron treatment. In this study, clear weather and high temperatures were experienced when the treatments were applied and conditions were conducive for optimal photosynthesis rates in both seasons. If a similar metamitron treatment coincides with periods of low temperature and low ambient light, the treatment could possibly result in a severe carbohydrate deficit stress that may lead to excessive fruit abscission (McArtney et al., 2012).

The application of metamitron did not increase the fruit size of 'Nadorcott' mandarin and the response was not related to the size of fruit at the time of treatment, or to the concentration of the active ingredient in the treatments; i.e., 150 and $300 \mathrm{mg} \cdot \mathrm{L}^{-1}$ metamitron (Table 1). The treatments had no direct effects on other fruit quality attributes in both seasons (Table 1). A slightly higher mean fruit weight for fruit treated with a $300 \mathrm{mg} \cdot \mathrm{L}^{-1}$ November metamitron treatment is most likely owing to the selective removal of the smallest fruit, than to a direct stimulation of the growth rate of the remaining fruit because no increase in the growth rates of the remaining fruit occurred in both seasons (Fig. 3). Previous studies have shown that to obtain a significant increase in fruit size through nonhormone-related fruit thinning, large number fruitlets has to be removed (Guardiola, 1988; Guardiola and García-Luís, 2000). Under South African conditions, however, fruit removal of as little as $15 \%$ by hand is sufficient to significantly increase fruit size in heavily fruiting 'Nadorcott' mandarin trees (Stander and Cronjé, 2016). The response is due to less interfruit competition of prevailing fruit, but in this study, a $25 \%$ reduction in fruit number in the same cultivar and under similar conditions had no effect on fruit size. It should be noted that although metamitron did lead to reduction of a much larger fruit number, the effect of the treatment was prolonged and reduced the carbohydrates available to remaining fruit for up to $60 \mathrm{~d}$ after treatment - a period of rapid fruit growth and in which fruit development is particularly sensitive to carbohydrate stress (García-Luís et al., 1988; Guardiola, 1988; Van Rensburg et al., 1996). Furthermore, it was not determined in this study whether fruit thinning was selective for smaller fruit or indiscriminate of fruit size. The effects of metamitron on leaf carbohydrates appeared to have nullified the gain in carbohydrates and the possible fruit size increase that typically results from fruit thinning. The treatments also did not have a direct stimulating effect on the sink strength of the 


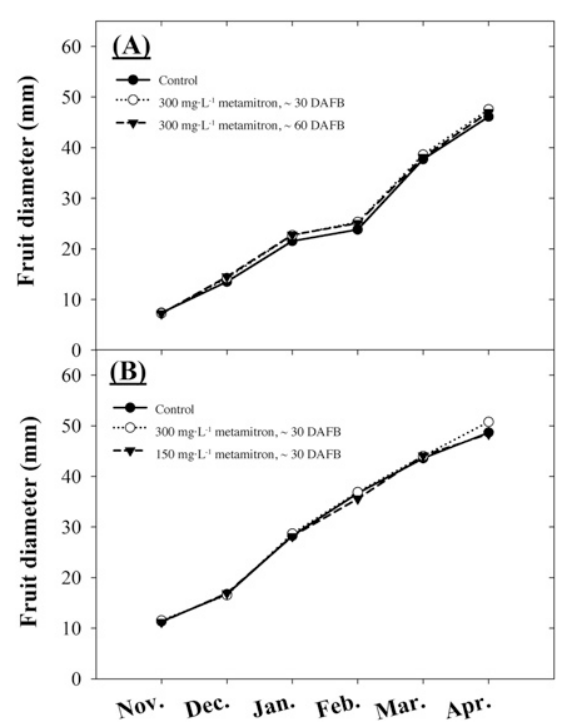

Fig. 3. Effects of different metamitron treatments on fruit growth in 'Nadorcott' mandarin: (A) $300 \mathrm{mg} \cdot \mathrm{L}^{-1}$ metamitron applied in Nov. $2015[\approx 30 \mathrm{~d}$ after full bloom (DAFB)] and $300 \mathrm{mg} \cdot \mathrm{L}^{-1}$ metamitron applied in Dec. 2015 ( $\approx 60$ DAFB) and (B) 300 and $150 \mathrm{mg} \cdot \mathrm{L}^{-1}$ metamitron applied in Nov. $2016(\approx 30$ DAFB). Data of 2015-16 (A) are expressed as means of eight replications, and seven replications for 2016-17 (B) $(n=7)$; $1 \mathrm{mg} \cdot \mathrm{L}^{-1}=1 \mathrm{ppm}, 1 \mathrm{~mm}=0.0394$ inch.

remaining fruit, which is achieved by the application of synthetic auxins (Guardiola and García-Luís, 2000 ).

In two citrus mandarin cultivars, Pixie (Verreynne and Lovatt, 2009) and Satsuma (Ehara et al., 1981; GarcíaLuís et al., 1995), fruit were shown to inhibit budbreak and the sprouting of new vegetative shoots during vegetative shoot flush in summer. Verreynne and Lovatt (2009) proved that this effect of excessive fruiting on budbreak was responsible for the perpetuation of alternate bearing in 'Pixie' mandarin, but that removal of fruit at an early stage can increase the number of new potential flower-bearing positions, and the flower intensity on parent shoots from which fruit were removed (Verreynne and Lovatt, 2009). Stander and Cronjé (2016) showed that fruit removal from heavily fruiting trees by summer increased fruit yield in the following season and reduced the severity of alternate bearing in 'Nadorcott' mandarin. Although a $300 \mathrm{mg} \cdot \mathrm{L}^{-1}$ metamitron treatment in this study did not influence fruit quality, the accompanied reduction in fruit number before the summer vegetative shoot flush could significantly affect alternate bearing by limiting the inhibiting effects of a heavy fruit load in season 1 , on return bloom, and fruit load in season 2 (Monselise and Goldschmidt, 1982).

\section{Conclusion}

Three experiments with metamitron were conducted during two fruiting seasons, in 2015-16 and 2016-17, on an experimental and a commercial citrus production orchard in Stellenbosch in South Africa. The results show that a foliar treatment of $150 \mathrm{mg} \cdot \mathrm{L}^{-1}$ metamitron effectively reduced leaf carbohydrates in citrus $\mathrm{l} d$ after treatment, and the effects of a $300 \mathrm{mg} \cdot \mathrm{L}^{-1}$ treatment on leaf carbohydrates persisted for up to $60 \mathrm{~d}$ after treatment. A single, medium volume foliar spray of $300 \mathrm{mg} \cdot \mathrm{L}^{-1}$ metamitron in a heavyset year at 4-6 weeks after full bloom when fruitlet size was $8-12 \mathrm{~mm}$ in transverse diameter, consistently reduced fruit number by $20 \%$ to $25 \%$. A reduction in fruit yield corresponded with an increase in concentration of metamitron treatment in the 1 year tested. A $300 \mathrm{mg} \cdot \mathrm{L}^{-1}$ treatment in November thinned more aggressively compared with a $150 \mathrm{mg} \cdot \mathrm{L}^{-1}$ treatment, in which the fruit yield was not different from the control. Metamitron treatment did not increase the fruit size of 'Nadorcott' mandarin and had no direct effect on other fruit quality attributes in both seasons. Metamitron can be used as a chemical fruit-thinning agent to reduce fruit numbers and possibly also control alternate bearing in 'Nadorcott' mandarin, but an increase in fruit size or quality did not occur. Similar rates of foliar metamitron treatment should be evaluated for fruit-thinning efficacy in different cultivars, and under typical spring field conditions in different South African citrus production regions.

\section{Literature cited}

Agustí, M., V. Almela, M. Aznar, M. El-Otmani, and J. Pons. 1994a. 'Satsuma' mandarin fruit size increased by 2,4-DP. HortScience 29:279-281.

Agustí, M., V. Almela, M. Juan, E. Primo-Millo, I. Trenor, and S. Zaragoza. 1994b. Effect of 3,5,6-trichloro-2-pyridyl oxyacetic acid on fruit size and yield of 'Clausellina' mandarin (Citrus unshiu Marc). J. Hort. Sci. 69:219-223.

Agustí, M., A. Martínez-Fuentes, and C. Mesejo. 2002. Citrus fruit quality. Physiological basis and techniques of improvement. Agrociencia 4:1-16.

Bain, J.M. 1958. Morphological, anatomical, and physiological changes in the developing fruit of the Valencia orange, Citrus sinensis (L). Osbeck. Austral. J. Bot. 6:1-23.

Basak, A. 2011. Efficiency of fruitlet thinning in apple 'Gala Must' by use of metamitron and artificial shading. J. Fruit Ornam. Plant Res. 19:51-62.

Brummer, Y. and S.W. Cui. 2005. Understanding carbohydrate analysis, p. 67-104. In: S.W. Cui (ed.). Food carbohydrates, chemistry, physical properties, and applications. CRC Press, Boca Raton, FL.

Cronjé, P.J.R. and O.P.J. Stander. 2016. Recommended fruit thinning strategies for the 2017 season. CRI Cutting Edge No. 225 .

Ehara, T., T. Nogata, and T. Nakamuta. 1981. Studies on fruit-bearing branches of 'Satsuma' mandarins. Proc. Intl. Soc. Citricult. 1:209-214.

El-Otmani, M., B. Kadri, A. Ait-Oubahouh, and M. Agustí. 1996. Use of auxins to improve fruit size of 'Clementine' mandarin-Effect on vegetative growth and fruit quality. Proc. Intl. Soc. Citricult. 2:1076-1080.

García-Luís, A., F. Fornés, and J.L. Guardiola. 1988. Competition and fruitlet abscission in 'Satsuma' mandarin. Proc. Intl. Soc. Citricult. 1:485-496.

García-Luís, A., M. Kanduser, and J.L. Guardiola. 1995. The influence of fruiting on the bud sprouting and flower induction responses to chilling in citrus. J. Hort. Sci. 70(5):817-825.

Goldschmidt, E. 1999. Carbohydrate supply as a critical factor for citrus fruit development and productivity. HortScience 34:1020-1024.

Guardiola, J.L. 1988. Factors limiting productivity in Citrus. A physiological approach. Proc. Intl. Soc. Citricult. 1:381-394.

Guardiola, J.L. and A. García-Luís. 1997. Thinning effects on citrus yield and fruit size. Acta Hort. 463:463-473.

Guardiola, J.L. and A. García-Luís. 2000. Increasing fruit size in Citrus. Thinning and stimulation of fruit growth. Plant Growth Regulat. 31:121-132. 
Iglesias, D.J., M. Cercós, J.M. Colmenero-Flores, M.A. Naranjo, G. Ríos, E. Carrera, O. Ruiz-Rivero, I. Lliso, R. Morillon, F.R. Tadeo, and M. Talón. 2007. Physiology of citrus fruiting. Braz. J. Plant Physiol. 19:333-362.

Iglesias, D.J., F.R. Tadeo, E. Primo-Millo, and M. Talón. 2003. Fruit set dependence on carbohydrate availability in citrus trees. Tree Physiol. 23:199-204.

Koch, N.C. 1995. Studies on the improvement of mandarin fruit size. Univ. Stellenbosch, Stellenbosch, South Africa, MSc Thesis.

Lafer, G. 2010. Effects of chemical thinning with metamitron on fruit set, yield, and fruit quality of 'Elstar'. Acta Hort. 884:531-536.

Mataa, M., S. Tominaga, and I. Kozaki. 1996. Seasonal changes of carbohydrate constituents in 'Ponkan' (Citrus reticulata Blanco). J. Jpn. Soc. Hort. Sci. 65:513-523.

McArtney, S.J. and J.D. Obermiller. 2012. Use of 1 -aminocyclopropane carboxylic acid and metamitron for delayed thinning of apple fruit. HortScience 47:1612-1616.

McArtney, S.J., J.D. Obermiller, and C. Arellano. 2012. Comparison of the effects of metamitron on chlorophyll fluorescence of and fruit set in apple and peach. HortScience 47:509-514.

Mesejo, C., A. Martínez-Fuentes, M. Juan, and M. Agustí. 2003. Vascular tissue development of citrus fruit peduncle is promoted by synthetic auxins. Plant Growth Regulat. 39:131-135.

Monselise, S.P. and E.E. Goldschmidt. 1982. Alternate bearing in fruit trees. Hort. Rev. 4:128-173.

Monselise, S.P., E.E. Goldschmidt, A. Golomb, and R. Rolf. 1983. Alternate bearing in citrus: Long-term effects of a single girdling treatment on individual 'Michal' tangerine branches. J. Amer. Soc. Hort. Sci. 108:373-376.

Rabe, E., N. Koch, and K. Theron. 1995. 2,4-DP (Corasil E) improves 'Clementine' mandarin fruit size. Citrus J. 5:27-30.

Rivas, F., Y. Erner, E. Alós, M. Juan, V. Almela, and M. Agustí. 2006. Girdling increases carbohydrate availability and fruit-set in citrus cultivars irrespective of parthenocarpic ability. J. Hort. Sci. Biotechnol. 81:289-295.

Ruiz, R., A. García-Luís, C. Monneri, and J.L. Guardiola. 2001. Carbohydrate availability in relation to fruitlet abscission in citrus. Ann. Bot. 87:805-812.
Schaffer, A.A., E.E. Goldschmidt, R. Goren, and D. Galili. 1985. Fruit set and carbohydrate status in alternate and nonalternate bearing citrus cultivars. J. Amer. Soc. Hort. Sci. 110:574-578.

South African Citrus Growers Association. 2016. South African Citrus Growers Association 2016 annual report. South African Citrus Growers Assn., Hillcrest, Kwazulu-Natal, South Africa.

Stander, O.P.J. and P.J.R. Cronjé. 2016. Reviewing the commercial potential of hand thinning in citrus with a cost-benefit analysis of summer hand thinning of 'Nadorcott' mandarin. HortTechnology 26:206-212.

Stern, R.A. 2014. The photosynthesis inhibitor metamitron is an effective fruitlet thinner for 'Gala' apple in the warm climate of Israel. Scientia Hort. 178:163-167.

Van Rensburg, P., P. Shung-Shi, A. García-Luís, and J.L. Guardiola. 1996. Improving crop value in 'Fino Clementine' mandarin with plant growth regulators. Proc. Intl. Soc. Citricult. 2:970-974.

Verreynne, J.S. and C.J. Lovatt. 2009. The effect of crop load on bud break influences return bloom in alternate bearing 'Pixie' mandarin. J. Amer. Soc. Hort. Sci. 34:299-307. 